\title{
Are Common Beliefs Present among Greek Academics during the Implementation of a Controversial University Policy?
}

\author{
Aggelos Kavasakalis (Corresponding author) \\ Dr., University of Patras \& Professor, Geitonas School, Athens \\ Dimokritou 18, 16343, Ilioupoli, Athens, Greece
}

Tel: 30-210-994-5991, 30-697-402-5628Ｅ-mail: a.kavasakalis@gmail.com

Received: June 3, 2013 Accepted: June 23, 2013 Published: July 3, 2013

doi:10.5296/ire.v1i1.3808 URL: http://dx.doi.org/10.5296/ire.v1i1.3808

\begin{abstract}
Universities have existed and have been developing for many centuries. They have experienced many changes since they first appeared. Nowadays the university is experiencing massification and internationalization. It is therefore interesting to investigate whether concrete common beliefs and values concerning the university do exist in the academic community. This article investigates, through a case study, such an existence among Greek academics during the implementation of a controversial university policy program. The research question, (i.e. the article's title) is answered through the elaboration of elements which emerged from the analysis of 35 semi-structured interviews with actors participating in policy networks that were activated during the processes of formation and implementation of the case study university policy program.
\end{abstract}

Keywords: higher education, academic beliefs, academic community, education policy

\section{Introduction}

This paper investigates the existence (or not) of a common academic culture, values and beliefs among Greek academics. This is accomplished by drawing elements from a policy issue which has been affecting the Greek university for over a decade. An institutionalized evaluation system of the Greek university has always been a policy issue that created political tension. Even before the beginning of the Bologna process unsuccessful attempts to legislate for and implement an evaluation system in the Greek university had been made (Law 2083/1992). After the opening of the Bologna process there were also attempts to establish a 
quality assurance and evaluation system in the Greek University (MoE draft Law 2003, Law3374/2005). Through confrontations, a few university department evaluations began to be carried out from 2008 onwards. Through this confrontation, two large coalition groups emerged among academics, one in favour of and the other against the institutionalized evaluation program as provided for in the law of 2005 (see Kavasakalis, 2011). The existence or absence of a system of core beliefs and values among Greek academics that were activated in the opposing, conflicting groups of networks for this policy program is one of them, and it is dealt with in the present paper.

\section{Developments and Transformation in European Universities}

\subsection{A Periodization of the History of European Universities}

The university is one of the oldest institutions in European history. As Berchem says: 'universities represent the memory of a society, including not only knowledge, but also values and experience. The university is among the longest-living formal institutions in the world - with the Catholic Church, being one of the very few others that have an even longer tradition' (Berchem, 2006, p. 395).

It is therefore necessary to examine the basic turning points in the history of European universities in order to proceed with this study's analysis of the existence (or not) of common values in the Greek university today.

Universities appeared during the twelfth century as corporations, associations of persons performing common tasks and defending their interests. By the middle of the thirteenth century they had received, through the intervention of popes, a canonic content by which a university was an institution that '[is] acknowledged or founded by a pope, whose members enjoy all the privileges granted to them by the pope, whose degrees are acknowledged throughout the Christian world on the pope's credence' (de Ridder-Symoens, 2006, p. 370). At the pre-Nation/State stage universities' core missions were teaching and research. The medieval universities, as far as their mission and basic organization were concerned, bore many similarities to the present institutions since they were legal corporations with the power to grant degrees, and also had a similar structure, being constituted of a curriculum, examinations, commencement, and faculties (Haskins, 1927, p. 369).

During the period of Nation/State 'nationalization, democratization, and public service missions developed to serve the needs of nation states. Ultimately, the missions of teaching and research were superimposed upon each of these missions' (Scott, 2006, p. 4). According to Rashdall universities throughout Europe in the course of the fifteenth century tended in the same direction - towards the nationalization (1936). It has to be mentioned that today most higher education institutions are national institutions which maintain more or less these five core missions. As Scott says 'most of Europe's and, hence, the world's universities are national institutions that retain the early modern mission of service to the state whether that state is free or totalitarian' (Scott, 1998, p. 110-111). Nor should we forget that the German university left many legacies for the modern university, such as the regular integration of the teaching and research missions; academic freedom regarding teaching, learning and research; 
the seminar method; laboratory instruction; monographic study; expansion of curriculum and fields of study; and applied research (Ben-David, 1977, p. 3585; Brubacher and Rudy, 1976, p. 174-175).

Nowadays, universities have reached a new stage in their existence. In the era of globalization where the nation/states are more interdependent the mission of internationalization has appeared. As Scott implies this new mission 'involves the existing multiple missions of university' (Scott, 2006, p. 5), but also 'internationalist and nationalist goals may conflict due to economic, political, or cultural differences. Despite the complexities, an apparent convergence of higher education policies is now afoot worldwide' (p. 30).

Today universities have to serve 'powerful external recruitment, employment, funding, professional and disciplinary constituencies and a range of gatekeeper expectations' (Silver, 2003, p. 166). They face the issue of the 'disintegration of knowledge and the threat of technological-scientific hegemony' (Grocholewski, 2006, p. 367), pressures from the 'entrepreneurial university which is subjected to the forces of the labor market, through contractual relationships between the professor producer - and the consumer student, each having well defined rights and duties, whether they be functional, practical, or applied teaching and research' (de Ridder-Symoens, 2006, p. 376). Finding a balance between continuity and change in order to answer the above challenges has to be the basic goal of modern universities. But reforms are part of the universities' heritage. They have 'shown enough flexibility and capacity to adjust, and have survived many depressions and crises. They were able to adapt to the requirements of a constantly changing society and of sometimes volatile governors' (de Ridder-Symoens, 2006, p. 376). Yet, 'universities have not just adapted their form: they have at the same time conserved their essence and their core values. It is this combination of adapting their form and preserving their core values that make universities relevant to modern society' (Sadlak et al., 2006, p. 349).

\subsection{European Universities: Core Beliefs, Values and Culture}

There is a discussion that takes place widely in different scientific fields, about the notion of culture, organizational culture (and so on) and the difficulties that this notion meets when it is used in theoretical and methodological frameworks. This paper does not intend to participate in these discussions. Instead the notion of 'culture' is only seen as a term that could satisfactorily combine the notions of a shared way of thinking and a collective way of behaving (Becher, 1984, p. 166). And since, as stated in another definition, (organizational) culture is 'the shared beliefs, ideologies, or dogma of a group which impel individuals to action and give their actions meaning' (Dill, 1982, p. 303-320) researchers should not underestimate the importance of either culture or of shared beliefs and values in order to understand how an organization functions. As far as academic culture is concerned, the notion presents some difficulties, not only due to the complex nature of the academic culture in institutions and in the academic profession (Clark, 1983, p. 72), but also because of the changes in universities that have been mentioned above which put pressure on the aims, values, policy and governance of higher education institutions (Findlow, 2012, p. 117). 
In general it could be claimed that the notion of academic culture has to do with a shared set of meanings, beliefs and values that academics possess. In short, 'a taken-for granted way of life, in which there is a reasonably clear difference between those on the inside and those on the outside of the [academic] community' (Barnett, 1990, p. 97). Moving to university activities, and if the functions of an organization are defined as the actions to be carried out in order to fulfill the organization's mission, then one could say that modern universities have multiple functions such as 'competitive higher education, competitive research, specialized services for the community, instance of critical evaluation of situations, and public commitment to values' (Marga, 2006, p. 433). Therefore, universities have had cultural commitments throughout their history; commitments which differentiate them from other organizations/institutions. And as Marga continues, higher education institutions' cultural legitimacy is defined as: 'the capacity of an institution and of the people who give life to institutions not only to pass on knowledge but also to grasp its meaning, not only to generate successors in the exercise of their profession, but also to form them for functioning in the changing environment, not only to operate with existing knowledge, but also to raise questions and increase it, not only to adapt to the technological, economic, administrative environment, but also to question it, not only to observe practices and values, be they one's own or pertaining to others, but also to question them explicitly, not only to integrate in the given culture but also to assume it as a life project, subject to validation in an increasingly complex world' (Marga, 2006, p. 433).

If one intends to isolate some specific core beliefs and values of higher education institutions throughout their history then s/he would end up with the notions of academic freedom (autonomy), the notion of institutional autonomy, the notion of production of new knowledge and the commitment to the society within which the university fulfills its role of public service and responsibility. For many academics and educators these core beliefs are necessary if the modern university wants to maintain its differentiation from other institutions. As Magyar implies 'academic freedom and institutional autonomy are absolute prerequisites to face the new challenges. Without these universities cannot perform their role' (Magyar, 2006, p. 391). But although many academics believe that these are the founding blocks of the universities' operation it is also necessary to reaffirm and clarify their significance. For example in the present situation it is necessary to re-define the core value of academic autonomy 'for the university as a higher education institution, for the professors, who work there, and the students who study there' (Filippov, 2006, p. 360).

Moreover, in modern conditions of massification and internationalization of higher education the existence of a distinguishable academic culture and common core beliefs and values among academics in the 21 st century has been in questioned. In the present period of the Age of Globalization as Berchem says there are many different constraints for universities. There are economic constraints expressed in the trend towards more financial and legal autonomy for the university, with a parallel reduction in governmental funding. There are political constraints due to national developments that influence educational structures and due to factors that are international and supranational. There are quality and competitive constraints as competitiveness and documentation - marketing of quality become more important within 
the university sector. And there are ethical constraints concerning fundamental questions such as 'what kinds of responsibility does a university have? Where are the limits of cooperation, both political and economic? In which areas do ethical factors prevail over competitive advantages?' (Berchem, 2006, p. 395-396).

Therefore, in a mass modern higher education system conflicts, uncertainty and difficulties in responding have become part of academics' everyday lives. In a paper in which Barnett questions the notion of academic culture, claims that: 'large multi-faculty universities - and even relatively small institutions - are a conglomerate of knowledge factions, interests and activities. We cannot assume that the manifold activities of the 'multiversity' have anything in common. It follows that the notion that there could be a single binding characteristic that all constituent parts of the university share, that there could be an essence, has to be suspect' (Barnett, 2000, p. 48). And as Silver implies 'the contemporary university may be conceived as a culture of tolerance of diversity, a culture of extreme diversity or a culture of fragmentation in tension, but these are ultimately unhelpful' (Silver, 2003, p. 167).

Researchers could identify, in the present situation, trends that challenge academic values and beliefs which were closely associated with the public-service responsibilities of universities and which were until recently regarded as a special feature of universities, distinct from skills training vocational education. As da Cruz summarizes the challenges/trends that pressure academic culture. In brief, the distortion of the notion of academic and institutional autonomy (up to the point of corporatism) due to the loss of meaning of social responsibility; the scientific and technical specialization that put university students' education at risk; the trend towards a mass university and its geographic dissemination which is connected to the shift from the creation of knowledge to its transmission; and the challenge of lifelong learning due to which the university has to cover the range of different needs of its students (da Cruz, 2006, pp. 400-401).

To conclude, historically the university has been regarded as a distinct institution, characterized by some common core beliefs and values. These, as have been reported in this paper, are:

(a) the university's commitment to the production and teaching of knowledge, (b) nationalization and internationalization missions, (c) democratization of society, (d) the university's commitment to public service and service to the community, (e) academic and institutional autonomy, (f) inviolable respect for the truth, (g) the university's reflective capacity, (h) the pursuit of justice, (i) a profound awareness of the dignity of the human person and (j) a spirit of social solidarity.

But nowadays it is to be asked whether changes and developments have resulted not only in pressure, but in shifts in academic values and core beliefs.

2.3 The Greek University and the Existence of Academics' Common Core Beliefs during the Implementation of a Controversial Policy Issue

To investigate the trends, pressures and changes in academic culture and values of Greek academics a controversial policy issue have been chosen. During such a policy program two 
conflicting academic networks were active. Their efforts to promote their beliefs in the policy program and its implementation reveal each network's beliefs and values system. The quality assurance (QA) policy program was chosen as a research case study, because if during a period of conflict certain common beliefs and values regarding the university do exist between the two opposing networks this means that this system of values and beliefs is solid and could be claimed to be deep core beliefs and values that could not be easily changed.

\subsubsection{Developments Concerning the Implementation of a QA System in Greek Universities}

The developments in the EHEA concerning QA (for a summarized documentation see Official Journal of European Communities, 1998; Bologna Process, 1999; 2001; 2005 and ENQA, 2005) put pressure at a national level for the establishment of a quality assurance law in the Greek higher education system. Prior to 2003 an institutionalized evaluation system had not been implemented. In this year the ministry of education (MoE) published a Draft-Law for the enactment of a quality assurance system (MoE - Draft Law, 2003). The MoE expected to have passed the law by the end of 2003, but national elections and a change of administration from the social democratic party of PASOK to the conservative party of New Democracy (ND), stopped the process.

The new administration's efforts concentrated on the passing of the law for quality assurance in 2005. In a summative form, this law provides for the implementation of evaluation procedures in two phases, internal and external, in Greek HE institutions every four years. Internal evaluation is carried out by the academic members of each department. The external evaluation is organized by an independent authority, the Hellenic Quality Assurance Agency for Higher Education. A final report based on the external evaluation has to be published (Law 3374/2005). The law was passed in July 2005. The law and its implementation processes follow the 'Standards and Guidelines for Quality Assurance in the European Higher Education Area' report that was produced by the E4 group and presented in the Bergen meeting of the Bologna process on 2005. It has to be mentioned though that public discussion was intense and the official dialogue was inevitably conflicting, especially during spring 2005 when the draft-law was published for further social consultation (Kavasakalis \& Stamelos, 2011, p. 38; Stamelos \& Kavasakalis, 2011, p. 356).

\section{Research Question and Methodology}

Both before and after the passing of Law 3374/2005, conflict regarding this policy program was always present. Since, as Henkel believes 'all the assessment systems are important for government's aims to reduce the universities' dependence on state funding and to instill market mechanisms into higher education [and] institutions' performance in the various forms of quality assessment is now crucial to them' (Henkel, 1997, p. 136) academics in Greek universities seem to act in different networks. Some of them were in favor of, and some against, the specific policy of institutionalized quality assurance.

The research question of this paper is: do common core beliefs and values regarding the university emerge among Greek academics that are active within conflicting networks concerning the QA policy program in Greek universities? 


\section{Macrothink}

Two methodological tools have been used. The main methodological tool was the conduct of qualitative semi-structured interviews. Policy document discourse analysis also took place in order to facilitate an initial investigation concerning data related to the policy program. The discussion topics of the semi-structured interviews were decided on by taking into consideration issues that resulted from public consultations with regard to the establishment and implementation of a quality assurance policy program in Greek universities. The 'axes of discussion' during the semi-structured interviews were: (a) the Greek university today, (b) educational policies for the 'European university', (c) the notion of quality and evaluation of universities, (d) law 3374/2005, (e) conditions and means of conduct of public dialogue concerning quality assurance in the Greek university and (f) proposals for a modern Greek university.

Thirty five semi-structured interviews were carried out. By elaboration of the produced texts the policy beliefs of each interviewee were structured and categorized. Finally, the composition of the belief systems of the opposing academics networks was worked out.

\section{Findings}

The first step in the research analysis was the construction of a belief system of actors belonging to one of the two coalition groups, that is to say, 'in favor of' and 'against' the specific university policy program. It is necessary to point out that the positioning of the interviewees within specific groups and finally within the groups 'in favor' and 'against ' is based only on their beliefs (as stated in the interviews) about the specific university policy program.

\subsection{Formation of Academics' Opposing Coalition Groups}

The composition of individual belief systems result in the belief systems of two opposing academic networks: the group of academics that are in favor of, and those that are against, the policy program. The following table presents the processed data obtained from the research. Detailed data is available in the wider research which examines the implementation of the specific policy program in Greek universities (see Kavasakalis, 2011).

At this point it has to be mentioned that the terminology used for the understanding of the different notions of quality (in the following table and forward) is derived from a work of Harvey and Green (1993). In their discussion of the relationship between quality and standards in higher education they identify different aspects of quality: quality as excellence, quality as fitness for purpose, quality as value for money, and quality as transformation. These different versions of quality promote different views about the role, the operation and philosophy of the university. 
Table 1. Belief systems of the two coalition groups of academics

\begin{tabular}{|c|c|}
\hline Belief system of academics acting in networks 'in favor' & Belief system of academics acting in networks 'against' \\
\hline \multicolumn{2}{|c|}{ Concerning the role and operation of the university } \\
\hline $\begin{array}{l}\text { - We have a more democratic institution due to expansion } \\
\text { policies. But these policies had either no planning or were } \\
\text { implemented under the effect of powerful political } \\
\text { pressures. This creates problems such as high economic } \\
\text { cost and in many cases the difficulty for university campus } \\
\text { culture to be present }\end{array}$ & $\begin{array}{l}\text { - The university is a public institution. It serves specific values } \\
\text { such as emulation, cooperation, equality, pluralism. } \\
\text { - Autonomy is a central concept for the university. It is } \\
\text { therefore necessary to address the single and tight institutional } \\
\text { framework, which constantly requires policies, especially in a } \\
\text { system of higher education with large differences }\end{array}$ \\
\hline $\begin{array}{l}\text { - A looser framework-law is needed so that real autonomy } \\
\text { and independence are possible }\end{array}$ & $\begin{array}{l}\text {-It is necessary to confront the continuous and deliberate } \\
\text { degradation of the public university }\end{array}$ \\
\hline $\begin{array}{l}\text { - Main characteristics of the university: internalization, } \\
\text { transparency, social accountability, quality assurance }\end{array}$ & $\begin{array}{l}\text { - University massification in Greece derived from unplanned } \\
\text { expansion policies, in conjunction with the important problem }\end{array}$ \\
\hline - Connection of the university with the needs of society & of under-funding and degradation. This must be addressed by \\
\hline $\begin{array}{l}\text { - Autonomy and independence need to be in balanced with } \\
\text { social accountability }\end{array}$ & the State \\
\hline
\end{tabular}

Concerning the notion of quality in the university

- The more powerful version of quality is 'quality as value for money'. Many networks also follow the version 'quality as fitness for purpose'

- The notion of quality is a complex one since it is related to the overall policy planning of-each university. But this difficulty should not be used as an excuse for not starting evaluation processes
- The notion of quality as 'transformation' (which develops critical thinking) is necessary in order to promote ethos and cooperation

- The debate on the concept of quality is a layered discussion, which never took place seriously

- The notion of quality and quality assurance inevitably belong to the university

Concerning evaluation and the university

- In favor of an institutionalized evaluation system, with internal evaluation as an obligatory stage

- The most important stage of an evaluation process is the 'after'. Evaluation findings should be used by the Ministry and the university so that the evaluation system will not end up as a formal, bureaucratic process

- The university is nowadays a massive, internationalized institution. Therefore, institutionalized evaluation that follows international standards is an important policy tool
- Evaluation should start from the university. There is no sense in an institutional system which relies mainly on external evaluation

- In favor of a system of internal evaluation aimed at capturing the opportunities, problems, but also the control of the State to comply with its obligations

- Evaluation should seek to reduce inequalities and the considerable variations among universities and Departments

Concerning European Education policies in the university (EEP)

- The Bologna process and more generally EEP 'push' the Greek university in the direction of positive reforms. It is positive that the Greek university tries, as part of these processes, to follow international developments

- EEP result in the internalization of the Greek university and research

- Due to European education programs the Greek university becomes, for the first time, a center for international research

- There are a few negative effects due to EEP, but the balance is positive

- The reaction to EEP stems from (a) ideological reasons and

(b) incomplete knowledge and analysis of them
- The Bologna process and EU policies (which are linked) mark a radical change in the institution of the European University to a 'business' university

- EEP occur without people taking part in their formation

- EEP promote the creation of two-tier universities

- European funding, although increasing the internationalization of the Greek university and the production of research, changes its values and functioning

- The university will act as a private company offering, especially in undergraduate studies, cheap and flexible services for education and research 


\subsection{Analysis of the Two Opposing Academic Groups' Belief Systems}

Analysis and comparison of the beliefs and values of the two groups of academics as reflected in the categorization of the views of academics who took part in the research has a dual purpose. Firstly, it shows the core differences between the two groups and therefore theoretically documents the formation of the two conflicting groups of academics. Secondly, it is necessary for answering the question of whether, even in a controversial policy issue for the Greek university, common core beliefs and values regarding the university emerge among Greek academics that are active within opposing networks concerned with the QA policy program in Greek universities.

\subsubsection{Differences in Beliefs and Values between the Two Groups of Academics}

Concerning the role and operation of the university, academics within networks 'in favor' consider the internationalization, accountability and flexibility of curricula to be essential so that the institution could closely monitor the needs of society and the market. Academics within networks 'against' believe that the university as a public educational institution should promote cooperation, equality and not diversity through policies of excellence and competition. It should aim at high-level research which will not be determined and driven by market' requirements.

For the different notions of quality and evaluation academics 'in favor' of the policy program opt for the version of quality as value for money, followed by the version of quality as fitness for purpose. Concerning evaluation they are convinced that institutionalized evaluation is necessary for the operation of the university since it is the primary tool for quality improvement and development. Academics belonging to the group 'against' consider that quality and evaluation are inherent characteristics of the university and for this reason there is no need to introduce any evaluation system based on external reviewers. The notion of quality that is strong among these academics is quality as transformation (development of critical thinking).

Analyzing the belief systems of the two groups of academics, it could be pointed out that the strongest differences which increase the tension during policy implementation are those related to the EEP and their effect on the university.

Academics acting within the coalition 'in favor' possess a positive attitude towards EEP, whether they come from the EU or from the Bologna process. They believe that EEP successfully promote collaboration, mobility, recognition of study periods and transparency due to the way that EHEA is formed and has developed. This results in positive reforms in European higher education systems and puts the European university at the center of the international higher education era. Due to EEP, they also believe that procedures of quality assurance, transfer of information and good practices between institutions but also between national systems are being developed. They also believe that reactions and negative attitudes of the opponent academics are not related mainly to a criticism of the core educational choices, values and ideas of the policies but are wider and are connected to an ideology which altogether rejects the EU structure. 
Academics acting within networks 'against' see policies derived either from the EU or the Bologna process as identical. They believe that both policies have been formed without the participation of the people of Europe and that both mark the transformation of the European university into an institution which operates as a private enterprise under conditions that are catastrophic for the university institution itself. They also consider that EEP aim at creating two-tier universities with a few universities of research and educational excellence and many moderate universities. Regarding quality assurance policies, they believe that these promote changes in curricula and in the general operation of the university. They believe that these policies forced universities in to an entrepreneurial and homogenized model of operating structure that strengthens enterprising competition through the idea of transparency together with the idea of comparability of European universities.

It could be concluded that significant differences in belief systems between the two groups of academics do exist. These differences explain the intensity in strategic interactions concerning issues of the QA policy program in Greek universities. Therefore the investigation of the presence of common beliefs, values and ultimately academic culture among opposing academics during the implementation of a controversial policy program for Greek universities, besides answering the paper's research question, is of interest to the Greek university community.

\subsubsection{Common Beliefs and Values between the Opposing Groups of Academics}

Regarding the role and operation of the Greek university there is agreement on the importance attached to the core concept of autonomy but also of social accountability for the university institution. Due to this belief academics from both networks believe that a loose operating framework should be developed for Greek universities so as to avoid the close embrace of the ministry leaderships which leads to the reduction of university independence. There is also agreement among academics regarding university expansion policies implemented in the previous two decades. They believe that these policies took place either without appropriate central policy planning or they succumbed to political or regional pressures. Therefore they both believe that the expansion of the Greek university system alongside the positive developments and conditions that have been created in Greek higher education, for example the rise in the access rate, or the university's commitment to public service; has created several structural, organizational and financial problems in the operation of the Greek higher education system.

Regarding the notion of university quality, Greek academics agree that quality is a multi-layered notion and the theoretical debate about this notion and how quality is connected to and affects the role, philosophy and operation of the university is a very complex debate that has not taken place thoroughly.

Concerning a quality assurance or evaluation system, both groups of academics agree that whatever evaluation system is implied, the results of its evaluation should be followed by a regenerative process. This process should reinforce the university department's strong points and detect and monitor the weak points. In the case of the latter, academics from both groups believe that for the weaknesses that are not related to the internal operation of the university 
but to wider policy issues related to the ministry or the State. They both believe that political leaderships should accept their responsibilities and provide help for the improvement of quality on these specific negative points.

Regarding European education policies and their impact, as has already been shown, there are considerable core differences between the two groups of academics. The only point of agreement is that the influx of funding through European research programs led to the internationalization of the Greek University and the expansion of research activities, something that both groups of academics consider to be a positive development.

From the data analysis it is quite clear that there seems to be agreement among academics in beliefs concerning key aspects of the Greek university, such as its philosophy and operation, its quality and evaluation processes. It is significant that this agreement appears in the data obtained from the survey on the belief systems of academics during the implementation of a policy program that caused conflicts in the area of Greek universities. Therefore, a minimum framework of common values, ideas and a common academic culture in Greek university seems to be present.

\section{Conclusion}

It could be claimed that through the analysis of the research on the production and implementation of an educational policy program of QA in Greek universities, academics seem to form two conflicting groups/networks one 'in favor of' and one 'against' the specific policy.

Through the comparison of beliefs of the two groups of academics it can be concluded that there are important differences associated either with the particular policy program or with wider issues concerning university and educational (European or national) policies. In particular, the differences in issues related to the European education policies could theoretically justify the intensity and the confrontation of conflicting academic networks. The tension that is produced in relation to these categories of beliefs is severe because the differences seem to transcend the specific educational policy program and to acquire a broader ideological background.

But at the same time the analysis of the data also showed that between the beliefs systems of the two groups of academics important agreements do exist.

It should also be mentioned that some of them are similar to the general core beliefs and values that have been presented in the paper's analysis concerning European universities' common values, beliefs and culture (-points a to $\mathrm{j}$ - as summarized at the end of section 2.2 European Universities: Core Beliefs, Values and Culture).

Greek academics from both of the opposing groups do promote beliefs and values about the university, such as: the university's commitment to the production and teaching of knowledge (point a), the internationalization missions (point b), the university's commitment to service to the community (point d), academic and institutional autonomy (point e) and the university reflective capacity (point g). And although there are many differences between their 
networks' beliefs systems, these common core beliefs do exist and are identical with the beliefs and values that are given to the university on a wider European level.

Therefore, the paper's analysis showed that there is a basic common framework of values and beliefs among academics in the Greek university. And this framework can be discerned even during intense clashes on education policy issues. And the answer to the research question is that even during the implementation of a controversial policy program, a joint academic culture that runs through the basic elements, the operation and the structure of the Greek university is maintained and constantly present.

\section{References}

Barnett, R. (1990). The Idea of Higher Education. Buckingham: Open University Press.

Barnett, R. (2000). Realizing the University in an Age of Supercomplexity. Buckingham: Open University Press.

Becher, T. (1984). The cultural view. In B. B. Clark (Ed.), Perspectives on Higher Education: eight disciplinary and comparative views. Berkeley CA: University of California Press.

Ben-David, J. (1977). Research. 1. History, purpose, and organization of academic research. International encyclopedia of higher education, 8, 3585-3590.

Berchem, Th. (2006). The University as an Agora - Based on Cultural and Academic Values. Higher Education in Europe, 31(4), 395-398. http://dx.doi.org/10.1080/03797720701303541

Bologna, D. (1999). Joint declaration of the European Ministers of Education. Bologna, 19.6.1999.

Bologna process. (2001). Towards the European Higher Education Area, Communique of the meeting of European Ministers in charge of Higher Education. Prague, 19 May 2001.

Bologna process. (2005). The European Higher Education Area - Achieving the Goals, Communique of the Conference of Ministers responsible for Higher Education. Bergen, 19/20-5-2005.

Brubacher, J. S., \& Rudy, W. (1976). Higher education in transition (3rd ed.). New York: Harper and Row.

Clark, B. R. (1983). The Higher Education System: academic organization in cross-national perspective. Berkeley CA: University of California Press.

da Cruz, M. (2006). Contemporary Challenges to European University Culture. Higher Education in Europe, 31(4), 399-401. http://dx.doi.org/10.1080/03797720701303590

de Ridder-Symoens, H. (2006). The University as European Cultural Heritage: A Historical Approach. Higher Education in Europe, 31(4), 369-379. http://dx.doi.org/10.1080/03797720701303160

Dill, D. D. (1982). The management of academic culture: notes on the management of meaning and social integration. Higher Education, 11, 303-320. 
http://dx.doi.org/10.1007/BF00155621

ENQA. (2005). Standards and Guidelines for Quality Assurance in the European Higher Education Area. Helsinki: ENQA.

Filippov, V. (2006). Defining the Principles of Cultural Heritage in the European Higher Education Area. Higher Education in Europe, 31(4), 359-361. http://dx.doi.org/10.1080/03797720701303087

Findlow, S. (2012). Higher education change and professional-academic identity in newly 'academic' disciplines: the case of nurse education. Higher Education, 63, 117-133. http://dx.doi.org/10.1007/s10734-011-9449-4

Grocholewski, C. Z. (2006). The European Cultural Heritage That Calls Out To Us. Higher Education in Europe, 31(4), 363-368. http://dx.doi.org/10.1080/03797720701303129

Harvey, L., \& Green, D. (1993). Defining quality. Assessment \& Evaluation in Higher Education, 18(1), 9-34. http://dx.doi.org/10.1080/0260293930180102

Haskins, C. H. (1927). The renaissance of the twelfth century. Cambridge MA: Harvard University Press.

Henkel, M. (1997). Academic Values and the University as Corporate Enterprise. Higher Education Quarterly, 51(2), 134-143. http://dx.doi.org/10.1111/1468-2273.00031

Kavasakalis, A. (2011). The establishment of a Quality Assurance mechanism on Greek University: the formation of Advocacy Coalition Policy Networks in the sub-system of Greek University. $\mathrm{PhD}$ thesis. University of Patras, Greece.

Kavasakalis A., \& Stamelos, G. (2011). 20 years of efforts to establish and implement a Quality Assurance System in Greek Higher Education. Mediterranean Journal of Social Sciences, 2(3), 35-45. http://dx.doi.org/10.5901/mjss.2011.v2n3p33

Law 2083. (1992). Modernization of Higher Education, Official Gazette of the Hellenic Republic, First Issue, No. 159, 21 September 1992 (in Greek).

Law 3374. (2005). Quality Assurance in Higher Education. Credit Transfer and Accumulation System. Diplomas Supplement, Official Gazette of the Hellenic Republic, First Issue, No. 189, 2 August 2005.

Magyar, B. (2006). Humanistic and Academic Core Values: The Responsive and Responsible Reform of the European University. Higher Education in Europe, 31(4), 391-394. http://dx.doi.org/10.1080/03797720701303343

Marga, A. (2006). The Cultural Legitimacy of the European University. Higher Education in Europe, 31(4), 425-438. http://dx.doi.org/10.1080/03797720701303897

MoE - Draft Law. (2003). National system of quality assurance and evaluation of higher education, Institutes of life-long learning, International Greek University and other provisions, Athens, September 2003 (in Greek). 


\section{Macrothink}

International Research in Education

ISSN 2327-5499

2013, Vol. 1, No. 1

Official Journal of European Communities. (1998). Recommendation of the Council of 24th September 1998 on European cooperation in quality assurance in higher education, (98/561/EC), L 270/56, 07.10.1998.

Rashdall, H. (1936). The universities of Europe in the Middle Ages (Vol. 1). Oxford: Oxford University Press.

Sadlak, J., Miller, J. M., \& Bergan, S. (2006). From the Joint Editors: The European University and Its Heritage - The Inspiration for Learning and Source of Knowledge based on Respect of Academic Values. Higher Education in Europe, 31(4), 347-350. http://dx.doi.org/10.1080/03797720701350138

Scott, J. C. (2006). The Mission of the University: Medieval to Postmodern Transformations. The Journal of Higher Education, 77(1), 1-39. http://dx.doi.org/10.1353/jhe.2006.0007

Scott, P. (1998). Massification, internationalization, and globalization. In P. Scott (Ed.), The globalization of higher education (pp. 108-129). Buckingham, UK: SRHE \& Open University Press.

Silver, H. (2003). Does a University Have a Culture?. Studies in Higher Education, 28(2), 157-169. http://dx.doi.org/10.1080/0307507032000058118

Stamelos, G., \& Kavasakalis A. (2011). The public debate on a Quality Assurance system for Greek universities. Quality in Higher Education, 17(3), 353-368. http://dx.doi.org/10.1080/13538322.2011.628807

\section{Glossary}

EEP: European education policies.

ENQA: European Association for Quality Assurance in Higher Education.

MoE: Ministry of education.

QA: Quality assurance.

\section{Copyright Disclaimer}

Copyright reserved by the author(s).

This article is an open-access article distributed under the terms and conditions of the Creative Commons Attribution license (http://creativecommons.org/licenses/by/3.0/). 